\title{
Operational Risk Management and Treatment af Technical Systems with Maintenance Support
}

Martin Stavek ${ }^{1}$, Zdenek Ales ${ }^{1}$, Vaclav Legat ${ }^{1}$, Adam Teringl ${ }^{2}$

${ }^{1}$ Faculty of Engineering, Czech University of Life Sciences Prague. Department for Quality and Dependability of Machines, Kamycka 129, 16521 Prague - Suchdol, Czech Republic. E-mail: stavek@tf.czu.cz, ales@tf.czu.cz, legat@tf.czu.cz

${ }^{2}$ NET4GAS, s.r.o., Na Hřebenech II 1718/8, 14021 Prague 4 - Nusle, Czech Republic. E-mail: Adam.Teringl@net4gas.cz

The purpose of this paper is to describe the area of risk management, in which maintenance can positively contribute to risk reduction and suggested reliability methods and maintenance tools can be used for risk treatment. The authors define the relationship between critical failure and risk and influence of preventive maintenance and redundancy on risk level. The risk level is defined as a product of critical failure probability and cost of critical failure losses. The proposed method enables to quantify risk treatment results. Benefits of the proposed risk treatment method based on preventive maintenance and redundancy applications are risk reduction and decreased costs (losses) of critical failure consequences within chemistry and nuclear power industrial technology. All decisions of maintenance have to be assessed according to economic criteria for specific objects and conditions in order to choose proper system maintenance.

Keywords: Maintenance, Risk Management, Preventive Maintenance, Redundancy, Risk Treatment

\section{Acknowledgement}

Paper was created with the grant support - CZU CIGA 2015 - 20153001 - Use of butanol in internal combustion engines.

\section{References}

[1] BS IEC 61882 (2001). Hazard and operability studies (HAZOP studies) - Application guide. British Standards Institution, London.

[2] BORKOWSKI S., STASIAK-BETLEJEWSKA R., NÁPRSTKOVÁ N. (2011). The Kaizen philosophy in the aluminium products improvement In: Manufacturing Technology, Vol. 11, No. 11, pp $2-5$.

[3] BURDUK, A., CHLEBUS, E. (2009). Evaluation of the risk in production systems with a parallel reliability structure. In: Eksploatacja i Niezawodność - Maintenance and Reliability Vol. 42, No. 2, pp. 84-95. Polska Akademia Nauk Oddział. Lublin.

[4] DIAN M. (2013). The Methodology of Quality Matrix in Manufacturing Quality Process Improvement In: Manufacturing Technology, Vol. 13, No. 4, pp 431 - 437.

[5] IEC 60050-191 (1990). International Electrotechnical Vocabulary: Chapter 191: Dependability and quality of service. Ed. 1.0. International Electrotechnical Commission. Geneva

[6] IEC 62198 (2001). Project risk management - Application guide. Ed. 1.0. International Electrotechnical Commission. Geneva

[7] ISO 31000 (2009). Risk management - Principles and guidelines. International Organization for Standardization. Geneva

[8] ISO Guide 73 (2009). Risk management - Vocabulary. International Organization for Standardization. Geneva

[9] LEGAT V., POSTA J., JURCA V., FLEGL R., HRNCIR P. (2007). Maintenance in quality and reliability management systems. (In Czech) ČSJ, Prague.

[10] LEGAT V, ZALUDOVA A H, CERVENKA V, JURCA V. (1996). Contribution to optimization of preventive replacement. Reliability Engineering and System Safety, Vol. 51, pp. 259 - 266. Elsevier Science Limited.

[11] LUKOVICS I, ČOP J, FOJTL L, LUKOVICS P, PATA V. Prediction of Surface Product Quality and Operation Reliability of Grinding Machines In: Manufacturing Technology, Vol. 14, No. 2, pp 213 - 217.

[12] MAYER K, PEXA M, PAVLU J. Impact of technical diagnostics interval on machinery maintenance. In: Manufacturing Technology, Vol. 12, No. 1, pp $42-46$.

[13] NĚMEC M. (2011). Přínos metody Six Sigma ke zvyšování efektivity výrobního procesu, Strojírenská technologie XVI Vol. July, No. 3, pp. 28 - 34 (In Czech).

[14] Out of control (2003). Why controls systems go wrong and how to prevent failure. 2nd ed. HSE Books. Sudbury.

[15] STASIAK-BETLEJEWSKA R. (2012). Value engineering as the way of quality problems solving in the steel construction management In: Manufacturing Technology, Vol. 12, No. 4, pp $242-247$

[16] WOJACZEK A, RUSIN A. (2012) Optimization of power machines maintenance intervals taking the risk into consideration. In: Eksploatacja i Niezawodność - Maintenance and Reliability, Vol. 14, No. 1, pp. 72-76. Polska Akademia Nauk Oddział. Lublin. 